\title{
Silencing of the $i c b-1$ gene inhibits the induction of differentiation-associated genes by vitamin D3 and all-trans retinoic acid in gynecological cancer cells
}

\author{
MARTINA HASELBERGER, ANETTE SPRINGWALD, ANNA KONWISORZ, CLAUS LATTRICH, \\ REGINA GOERSE, OLAF ORTMANN and OLIVER TREECK
}

Department of Obstetrics and Gynecology, University Medical Center Regensburg, Regensburg, Germany

Received February 4, 2011; Accepted March 11, 2011

DOI: $10.3892 / \mathrm{ijmm} .2011 .663$

\begin{abstract}
I c b-1$ (C1orf38) is a human gene initially described by our group to be involved in differentiation processes of cancer cells. To further elucidate the function of the $i c b-1$ gene in differentiation of breast and endometrial cancer cells, we knocked down its expression by means of shRNA transfection. Knockdown of $i c b-1$ inhibited the vitamin $\mathrm{D}_{3}$-induced up-regulation of E-cadherin expression in both MCF-7 and HEC-1B cells. Induction of E-cadherin expression by all-trans retinoic acid (ATRA) was also blocked in both cell lines expressing $i c b-1$ siRNA. Examination of $i c b-1$ and E-cadherin expression in 66 breast cancer tissue samples revealed a significant positive correlation between the two genes. In MCF-7 cells, silencing of the $i c b-1$ gene inhibited the ATRA- and the vitamin $\mathrm{D}_{3}$-induced up-regulation of lactoferrin and estrogen receptor $\beta$ expression. The data of our knockdown study suggest that $i c b-1$ may act as a mediator of differentiation signals in breast cancer cells induced by ATRA or vitamin $D_{3}$. These findings together with the observed co-expression of $i c b-1$ with E-cadherin in breast cancer samples support an important role of the $i c b-1$ gene in cancer cell differentiation.
\end{abstract}

\section{Introduction}

The human gene $i c b-1$ (C1orf38, chromosome 1 open reading frame 38 ) is a member of the new metazoan gene family THEMIS coding for cytosolic proteins which bind to the Grb2 adaptor protein involved in receptor tyrosine kinase signaling (1,2). Icb-1 was originally cloned and identified by our group in an attempt to analyze gene expression changes during in vitro differentiation of endometrial tumor cells (3).

Correspondence to: Dr Oliver Treeck, Department of Obstetrics and Gynecology, University of Regensburg, Caritas Krankenhaus St. Josef, Landshuter Strasse 65, D-93053 Regensburg, Germany

E-mail: otreeck@caritasstjosef.de

Key words: Clorf38 gene, icb-1 gene, differentiation, cancer cell line, breast cancer
We reported a strong increase of $i c b-1$ expression in HEC-1B endometrial adenocarcinoma cells cultured on an artificial basement membrane. Ic $b-1$ expression was also elevated during monocytic and granulocytic in vitro differentiation of promyelocytic leukemia cells induced by all-trans retinoic acid (ATRA) or vitamin $\mathrm{D}_{3}$ (4). These early reports clearly suggested that $i c b-1$ may be involved in such differentiation processes of cancer cells. Further studies demonstrating that $i c b-1$ is an interferon- $\gamma$ responsive gene, which in turn inhibits the effects of this cytokine on tumor cells, also support that $i c b-1$ may have a role in the immune response (5). We later identified an estrogen response element (ERE) in the promoter region of the $i c b-1$ gene and demonstrated its expression to be estrogen-inducible in breast and ovarian cancer cells and to be dependent on estrogen receptor $\alpha(E R \alpha)(6)$. Data of our recent study further support the presence of a cross-talk between $i c b-1$ and ER-signaling. Stable knockdown of $i c b-1$ in breast and ovarian cancer cells significantly increased the cellular estrogen response in terms of proliferation and gene expression, suggesting that $i c b-1$ may exert antagonistic actions on the cellular estrogen response (7). These hypotheses are further supported by our results showing that single nucleotide polymorphisms in the icb- 1 gene are able to affect breast cancer susceptibility (8). The identification of $i c b-1$ as a new player in hormone-dependent cancer encourages further studies on the significance of this gene in cancer.

The previously observed regulation of $i c b-1$ expression by ATRA and vitamin $\mathrm{D}_{3}$ in leukemia cells prompted us to investigate whether $i c b-1$ knockdown would affect the response of gynecological tumor cells to these differentiating drugs. ATRA and vitamin $D_{3}$ have both been reported to induce differentiation of breast cancer cells, an effect accompanied by an increase of E-cadherin expression $(9,10)$. Lactoferrin expression is a marker for differentiated mammary epithelial cells and has been shown to be regulated by ATRA and to contain a retinoic acid response element in its promoter $(11,12)$. With regard to the endometrium, both vitamin $\mathrm{D}_{3}$ and ATRA have been shown to induce differentiation of endometrial adenocarcinoma cells $(13,14)$. In endometrial cancer, cellular differentiation has been associated with E-cadherin expression, and partial or complete loss of E-cadherin expression has been correlated with malignancy (15). 
In the present study, in order to further elucidate the function of the $i c b-1$ gene in breast and endometrial cancer cells, we used RNA interference to generate cancer cells with silenced $i c b-1$ expression. After stable transfection of MCF-7 breast cancer cells and HEC-1B endometrial adenocarcinoma cells with an $i c b-1$ shRNA vector, we examined the regulation of different differentiation-associated genes in both cell lines. Additionally, we analyzed the co-expression of the $i c b-1$ gene with these differentiation markers in 66 breast cancer tissue samples.

\section{Materials and methods}

Materials. Phenol red-free DMEM culture medium was obtained from Invitrogen (Karlsruhe, Germany) and FCS was purchased from PAA (Pasching, Austria). All-trans retinoic acid (ATRA) and 1,25 $(\mathrm{OH})_{2} \mathrm{D}_{3}$ (vitamin $\left.\mathrm{D}_{3}\right)$ were obtained from Sigma (Deisenhofen, Germany), MCF-7 breast cancer cells and HEC-1B endometrial adenocarcinoma cells were obtained from American Type Culture Collection (Manassas, VA, USA). M-MLV-P reverse transcriptase was purchased from Promega (Mannheim, Germany). The RNeasy mini kit, the RNase-free DNase set and the Quantitect SYBR-Green PCR kit were obtained from Qiagen (Hilden, Germany). PCR primers were synthesized at Metabion (Planegg-Martinsried, Germany). Transfectin reagent was obtained from Bio-Rad (Hercules, CA, USA). The Platinum Pfx polymerase and the OptiMEM medium were purchased from Invitrogen. The SureSilencing shRNA plasmid for the human $i c b-1$ (C1orf38) gene was purchased from SABiosciences (Frederick, MD, USA).

Patients. Breast cancer tissue samples were collected between 2007 and 2009 by the Clinic of Obstetrics and Gynecology, Medical University of Regensburg, Germany, during routine surgery of the patients. From the 66 breast cancer samples, 22 were graded G1 and were ER $\alpha$-positive, 22 were G3 and ER $\alpha$-positive and 22 were G3 and ER $\alpha$-negative. All patients granted consent for the collection and use of biologic material. Tissue samples of patients were collected in accordance with German regulations and in agreement with the Ethics Committees of the Medical University of Regensburg. Complete clinical data were available for every patient. Immediately following surgery, tissues were stored in liquid nitrogen until RNA extraction.

Cell culture and transfections. MCF-7 breast cancer cells were maintained in DMEM/F12 medium supplemented with $10 \% \mathrm{FCS}, 1 \mathrm{mM}$ sodium pyruvate and $10 \mathrm{ng} / \mathrm{ml}$ insulin. HEC-1B cells were cultured in DMEM/F12 medium with $10 \%$ FCS. Cells were cultured with $5 \% \mathrm{CO}_{2}$ at $37^{\circ} \mathrm{C}$ in a humidified incubator. For transfection, $10^{6}$ cells/well were seeded in a 6 -well dish in DMEM/F12 containing 10\% FCS. The next day, $1.2 \mathrm{ml}$ of fresh culture medium were added to the cells and transfection solution was prepared by mixing $8 \mu \mathrm{l}$ Transfectin reagent (Bio-Rad) and $1 \mu \mathrm{g}$ of the shRNA plasmid mix or control plasmid DNA in OptiMEM-reduced serum medium (Invitrogen) and added to the cultured cells. Transfection with $i c b-1$ shRNA was performed with a mixture of four plasmids (SureSilencing, SABiosciences) containing the $i c b$-l-specific
shRNA insert sequences, 5'-gggagtagctttgtggaaact-3', 5'-cacc tgagcttctctatgaat-3', 5'-gtagcaccaagcctgatagat-3' and 5'-cat ggattaatgtgggaactt- $3^{\prime}$ which bind to the $i c b-1$ exon 6 present in all splice variants. The same plasmid with the non-specific insert 5'-ggaatctcattcgatgcatac-3' was used as a negative control. For generation of stable clones, $48 \mathrm{~h}$ after transfection, G418 selection ( $300 \mu \mathrm{g} / \mathrm{ml})$ was initiated and lasted for about 6 weeks before the first clones were isolated.

RNA preparation and real-time PCR. Total RNA from breast cancer tissue samples was isolated from 30-80 mg frozen tissue by means of the TRIzol reagent (Invitrogen) according to manufacturer's protocol. Total RNA from the cell lines was isolated by means of the SV total RNA isolation system (Promega) according to the manufacturer's instructions. RNA purity and concentration were determined by spectrophotometry. From each sample, $500 \mathrm{ng}$ of total RNA were reverse transcribed to cDNA using 40 units of M-MLV reverse transcriptase and RNasin (Promega) with $80 \mathrm{ng} / \mu \mathrm{l}$ random hexamer primers (Invitrogen) and $10 \mathrm{mM}$ dNTP mixture (Fermentas, St. Leon-Rot, Germany) according to the manufacturer's instructions. After reverse transcription, the levels of the $i c b-1$ and marker gene transcripts were determined by real-time PCR. For this purpose, $4 \mu \mathrm{l}$ of cDNA were amplified using LightCycler ${ }^{\circledR}$ FastStart DNA Master ${ }^{\text {PLUS }}$ SYBR-Green I (Roche Diagnostics GmbH, Mannheim, Germany) and $5 \mathrm{mM}$ of each primer (Table I). The designed oligonucleotides (Metabion) were intron-spanning in order to avoid genomic contaminations. The primers for $i c b-1$ amplification were designed to bind at the borders of exons 1 and 2, or 2 and 3, respectively, and thus were able to bind to the icb-1 mRNA and to all splice variants exhibiting the three first exons.

Real-time PCR was carried out in the LightCycler $^{\circledR} 1.0$ Instrument (Roche) under the following conditions: initial denaturation at $95^{\circ} \mathrm{C}$ for $15 \mathrm{~min}$, followed by 40 cycles with $10 \mathrm{sec}$ denaturation at $95^{\circ} \mathrm{C}, 5 \mathrm{sec}$ annealing at $60^{\circ} \mathrm{C}$ and $12 \mathrm{sec}$ extension at $72^{\circ} \mathrm{C}$. The PCR program was completed by a standard melting curve analysis. Negative controls were prepared by adding distilled water instead of cDNA. To verify the identity of the PCR products, they were also analyzed by electrophoresis in $1.5 \%$ agarose gels and stained with ethidium bromide. After verification of the band size, each PCR product was purified using the QIAquick gel extraction kit (Qiagen), following the manufacturer's protocol followed by sequencing verification (Eurofins MWG Operon, Ebersberg, Germany). In all real-time PCR experiments, a 190 bp $\beta$-actin fragment was amplified as reference gene using the intron-spanning primers actin-2573 and actin-2876. Data were analyzed using the comparative $\Delta \Delta \mathrm{C}_{\mathrm{T}}$ method (16) calculating the difference between the threshold cycle $\left(\mathrm{C}_{\mathrm{T}}\right)$ values of the target and reference gene of each sample and then comparing the resulting $\Delta \mathrm{C}_{\mathrm{T}}$ values between different samples.

Western blot analysis. Cancer cells were lysed in RIPA buffer [1\% (v/v) Igepal CA-630, 0.5\% (w/v) sodium deoxycholate, $0.1 \%$ $(\mathrm{w} / \mathrm{v})$ sodium dodecyl sulphate (SDS) in phosphate-buffered solution (PBS) containing aprotonin and sodium orthovanadate]. Aliquots containing $15 \mu \mathrm{g}$ of protein were resolved by $10 \%$ (w/v) SDS-polyacrylamide gel electrophoresis, followed by electrotransferring to a PVDF hybond (Amersham, UK) 
Table I. PCR primer sequences used for qPCR.

\begin{tabular}{llc}
\hline Transcript & \multicolumn{1}{c}{ Primers (5'-3') } & Amplicon (bp) \\
\hline Icb-1 & TCGAGGGCTCCATCTATGA & 155 \\
& GAAGTAGCCCTGGAAGTTGG & \\
ER $\alpha$ & CACATGAGTAACAAAGGCATGG & 181 \\
ER $\beta 1$ & ATGAAGTAGAGCCCGCAGTG & 181 \\
ERCATGCGAGTAACAAGGGC $\beta 2$ & GGGAGCCCTCTTTGCTTT & 177 \\
E-cadherin & GTTTGGGTGATTGCAAGAG & 101 \\
Lactoferin & TCTGCCCTCGCATG & 150 \\
& GCCACATACACTCTCTTCTCTCAC & \\
& AGCACCTTCCATGACAGACC & 136
\end{tabular}

membrane. Immunodetection was carried out using C1ORF38/ ICB-1 antibody (clone DO1P, Abnova, Germany) or a $\beta$-actin antibody (8226, Abcam, Germany) diluted 1:5,000 in PBS containing $5 \%$ skim milk (w/v) followed by incubation with a horseradish peroxidase-conjugated secondary antibody. The bands were visualized using a chemiluminescence (ECL) system (Amersham, Buckinghamshire, UK).

Statistics. Statistical analysis of the data was carried out using the InStat software (GraphPad, San Diego, USA). Evaluation of the significance of the differences between the gene expression in the tumor and the normal endometrium group was performed by means of the non-parametric Mann-Whitney test; comparison of the three subgroups was carried out using the non-parametric Kruskal-Wallis test. The correlation of the $i c b-1$ expression with the marker gene expression was assessed by means of the Spearman non-parametric test.

\section{Results}

Regulation of icb-1 expression by shRNA, vitamin $D_{3}$ or $A T R A$. Icb-1 was identified as a transcript with increased expression after in vitro differentiation of endometrial tumor or leukemia cells induced by their exposure to a reconstituted basement membrane (Matrigel), ATRA or vitamin $\mathrm{D}_{3}(3,4)$. In the present study, we first examined the effects of ATRA and vitamin $\mathrm{D}_{3}$ on $i c b-1$ expression in the MCF-7 and HEC-1B tumor cell lines. Treatment of MCF-7 breast cancer and HEC-1B endometrial adenocarcinoma cells with vitamin $\mathrm{D}_{3}$ $(100 \mathrm{nM})$ for $48 \mathrm{~h}$ resulted in a significant increase of $i c b-1$ transcript levels (Fig. 1). In contrast, treatment with ATRA at concentrations up to $1 \mu \mathrm{M}$ did not significantly affect the expression of this gene.

To examine the role of $i c b-1$ in the differentiation of cancer cells from the breast and the endometrium, we knocked down its expression by means of RNA interference. For this purpose, we transfected MCF-7 and HEC-1B cells with $i c b-1$ shRNA plasmids as described earlier (7). After 8 weeks of G418 selection, different clones were isolated and $i c b-1$ knockdown

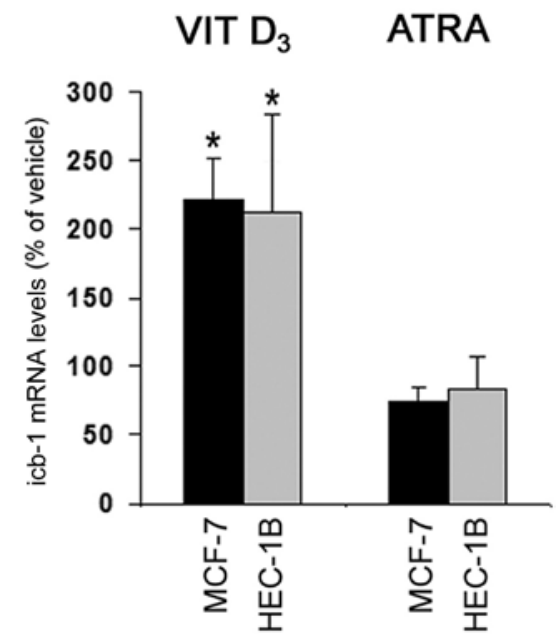

Figure 1. Effect of vitamin $\mathrm{D}_{3}\left(\mathrm{VIT}_{3}\right)$ and ATRA on the $i c b-1$ gene mRNA levels as determined by real-time PCR. The indicated cell lines were treated with $100 \mathrm{nM}$ VIT $\mathrm{D}_{3}$ or $1 \mu \mathrm{M}$ ATRA for $48 \mathrm{~h}$ and the total RNA was isolated as described in Materials and methods. Values are expressed as percent of the vehicle control. ${ }^{*} \mathrm{p}<0.05$ vs. vehicle $(\mathrm{n}=3)$.

was verified both by means of real-time PCR and by Western blot analysis (Fig. 2). Icb-1 transcripts were detected in both cell lines, but their levels turned out to be about $67 \%$ lower in MCF-7 than in HEC-1B cells. These results may help explain why we were only able to detect the ICB-1 protein by means of Western blot analysis in the latter cell line. However, we judged that the functionality of the used icb-1 siRNA as demonstrated by the inhibition of the mRNA levels in both cell lines and of the protein levels in HEC-1B cells, was sufficient to warrant the continuation of this study. We chose one clone per cell line, exhibiting the best $i c b-1$ knockdown effect ( $~ 80 \%$ of the mRNA level) for the following experiments, termed MCF-7 $i c b K D$ and HEC-1B $i c b K D$.

Effect of icb-1 gene silencing on lactoferrin and E-cadherin expression and regulation. To study the role of $i c b-1$ in the cellular differentiation of breast and endometrial tumor 
A

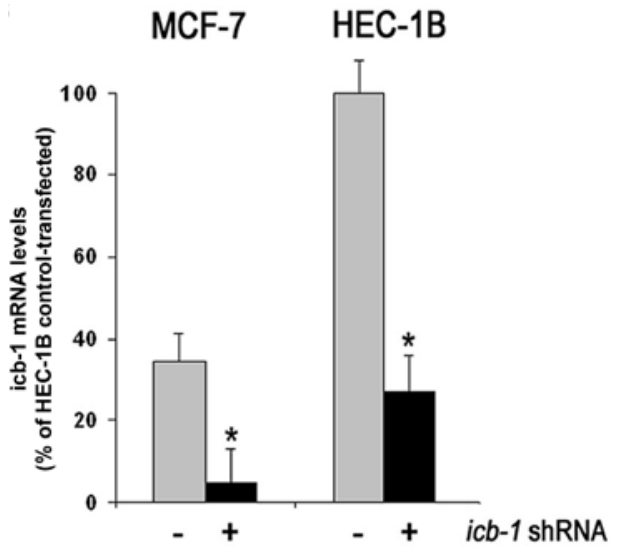

B



Figure 2. Effects of $i c b-1$ gene expression knockdown after stable transfection with an icb-1 shRNA vector on (A) the mRNA levels as determined by realtime PCR and (B) on protein levels as determined by Western blot analysis in HEC-1B cells. After G418 selection for 8 weeks, total RNA and cell lysate were isolated as described in Materiala and methods. Values are expressed as percent of the control plasmid. " $\mathrm{p}<0.05$ vs. control plasmid $(\mathrm{n}=3)$.

\section{E-cadherin}


Figure 3. Expression of E-cadherin and lactoferrin in cancer cells expressing $i c b-1$ shRNA. Total RNA was isolated from $i c b \mathrm{KD}$ (knockdown) and control-transfected cells, as described in Materials and methods. mRNA expression of the indicated genes was analyzed by means of real-time PCR Values are expressed as percent of the expression in control-transfected cells. " $\mathrm{p}<0.05$ vs. control plasmid $(\mathrm{n}=3)$; $n$ nd, lactoferrin mRNA was not detected in HEC-1B cells.

cells, we decided to examine the expression changes of a set of differentiation-associated genes induced by the $i c b-1$ knockdown. Transcript levels of the epithelial cell marker, E-cadherin were not significantly affected by the RNAi-
A


B

\section{E-cadherin}

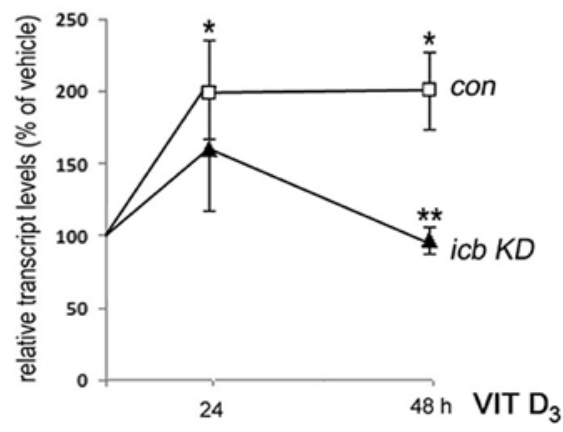

Figure 4. Effects of $I c b-1$ knockdown on the vitamin $\mathrm{D}_{3}$-induced activation of E-cadherin and lactoferrin expression. MCF-7 cells (A) or HEC-1B cells (B) were treated for $48 \mathrm{~h}$ with $100 \mathrm{nM} 1,25(\mathrm{OH})_{2} \mathrm{D}_{3}$ (VIT $\mathrm{D}_{3}$ ). Total RNA was isolated from treated $i c b \mathrm{KD}$ (knockdown) cells and control-transfected cells, as described in Materials and methods. mRNA expression of the indicated genes was analyzed by means of real-time PCR. Values are expressed as percent of the vehicle control. " $\mathrm{p}<0.05$ vs. vehicle ( $\mathrm{n}=6)$.

mediated silencing of the $i c b-1$ gene neither in MCF-7 nor in HEC-1B cells (Fig. 3). In contrast, expression of lactoferrin, which was exclusively detected in MCF-7 cells, was increased about 5-fold in MCF-7 icbKD cells.

Given that treatment with vitamin $\mathrm{D}_{3}$ elevated $i c b-1$ expression in both cell lines and this drug is known to increase E-cadherin expression, we further examined whether the gene regulatory effect of vitamin $\mathrm{D}_{3}$ was affected by $i c b-1$ knockdown. After treatment with $100 \mathrm{nM}$ vitamin $\mathrm{D}_{3}$ for $48 \mathrm{~h}$, E-cadherin transcript levels significantly increased by $70 \%$ in MCF-7 cells and by 95\% in HEC-1B cells (Fig. 4). This effect of vitamin $\mathrm{D}_{3}$ was totally absent in both cell lines expressing $i c b-1$ shRNA. Treatment of MCF-7 cells with vitamin $\mathrm{D}_{3}$ also up-regulated lactoferrin transcript levels up to $238 \%$ of the vehicle control. Similarly to the effect on E-cadherin 
A
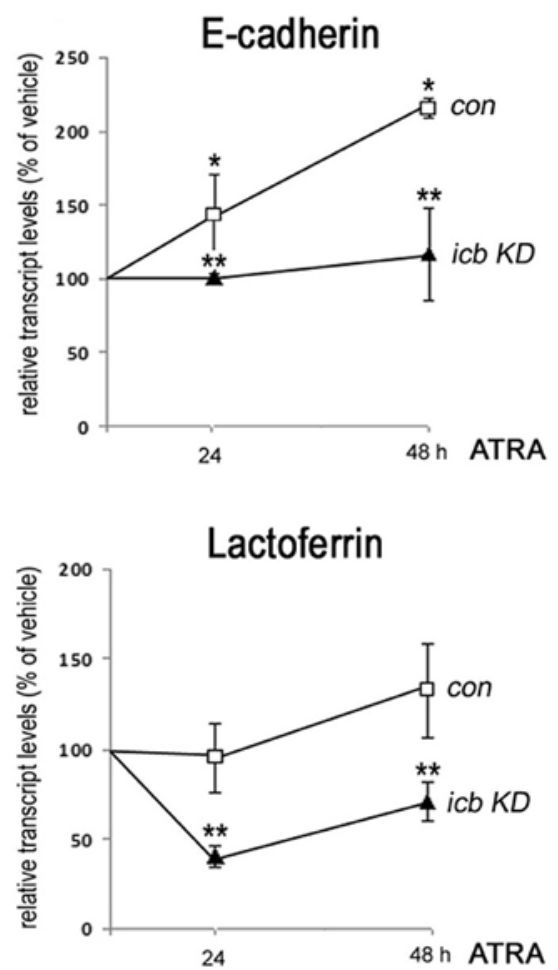

B

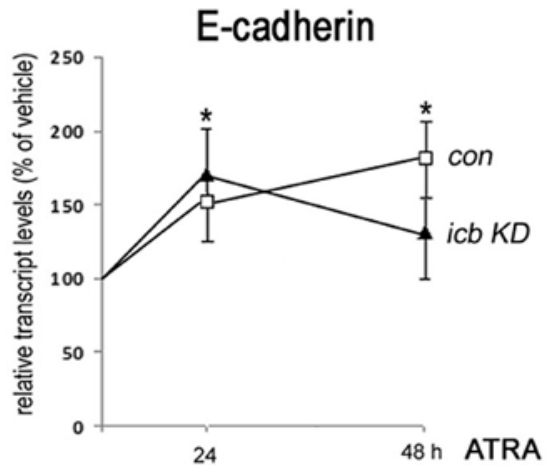

Figure 5. Effects of $I c b-1$ knockdown on the ATRA-induced activation of E-cadherin and lactoferrin expression. MCF-7 cells (A) or HEC-1B cells (B) were treated for $48 \mathrm{~h}$ with $1 \mu \mathrm{M}$ ATRA. Total RNA was isolated from treated $i c b K D$ (knockdown) cells and control-transfected cells, as described in Materials and methods. Expression of the indicated genes was analyzed at the mRNA level by means of real-time PCR. Values are expressed as percent of the vehicle control. ${ }^{*} \mathrm{p}<0.05$ vs. vehicle $(n=6)$.

transcript levels, the effect on lactoferrin transcript levels was not detected in MCF-7 icbKD cells.

ATRA is also a drug well known to induce differentiation of various cell types. Treatment with ATRA nearly doubled E-cadherin expression in MCF-7 breast cancer cells, and elevated transcript levels of this gene by $\sim 70 \%$ in HEC-1B cells. This effect of ATRA was totally blocked in MCF-7 $i c b \mathrm{KD}$ cells, and was significantly weakened in HEC-1B $i c b \mathrm{KD}$ cells (Fig. 5). Exposure to ATRA also increased lactoferrin transcript levels in MCF-7 cells, wheras this drug down-regulated this gene in the presence of $i c b-1$ shRNA.

Effect of icb-1 gene silencing on ER $\beta$ gene regulation by $A T R A$ and vitamin $D_{3}$. Given that expression of steroid hormone receptors is another indicator for the grade of
A

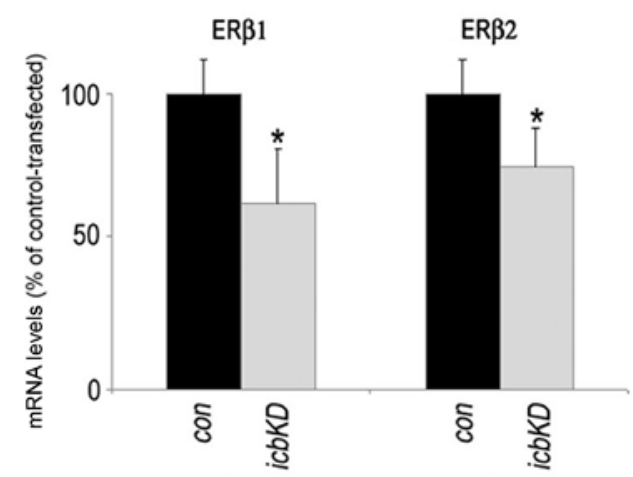

B


Figure 6. Effects of $I c b-1$ knockdown on estrogen receptor $\beta$ (ER $\beta$ ) expression. (A) Reduction of ER $\beta 1$ and ER $\beta 2$ mRNA levels in ic $b$ KD (knockdown) cells as determined by real time RT-PCR. (B) Knockdown of $i c b-1$ blocks up-regulation of ER $\beta 1$ and ER $\beta 2$ mRNA levels by ATRA or VIT $D_{3}$ in MCF-7 breast cancer cells. Cells were treated for $48 \mathrm{~h}$ with $1 \mu \mathrm{M}$ ATRA or $100 \mathrm{nM}$ VIT $\mathrm{D}_{3}$. Total RNA was isolated from treated $i c b \mathrm{KD}$ cells and control-transfected cells, as described in Materials and methods. Expression of ER $\beta 1$ and ER $\beta 2$ at the mRNA level was analyzed by means of real-time PCR. Values are expressed as percent of the control-transfected cells (A) or of the vehicle control (B). " $\mathrm{p}<0.05(\mathrm{n}=6)$.

de-differentiation of breast and endometrial cancer cells, we next examined the effect of the knockdown of the $i c b-1$ gene on the ATRA- and vitamin $\mathrm{D}_{3}$-induced alterations on the expression of $\mathrm{ER} \alpha$ and $\mathrm{ER} \beta . \mathrm{ER} \alpha$ transcript levels were slightly elevated in both cell lines expressing $i c b-1$ shRNA but were not affected by either drug (data not shown). On the other hand, the expression of ER $\beta 1$ and ER $\beta 2$ was decreased in the presence of $i c b-1$ shRNA (Fig. 6A). When MCF-7 cells were treated with ATRA for $48 \mathrm{~h}$, the transcript levels of both ER $\beta$ variants were elevated by $30-40 \%$. In contrast, in MCF-7 icbKD cells ATRA induced a significant down-regulation of 
Table II. Correlation of $i c b-1$ expression with the expression of the indicated genes in breast cancer tissue samples.

\section{$i c b-1$}

\begin{tabular}{lcrl}
\cline { 2 - 4 } & $\begin{array}{c}\text { Spearman's rho } \\
\text { (corrected for ties) }\end{array}$ & $95 \% \mathrm{CI}$ & p-value \\
\hline E-cadherin & 0.2665 & $0.05284-0.4569$ & $0.0126^{\mathrm{a}}$ \\
ER $\alpha$ & 0.2421 & $0.02680-0.4360$ & $0.0239^{\mathrm{a}}$ \\
ER $\beta 1$ & -0.1577 & $-0.3620-0.06117$ & 0.1447 \\
ER $\beta 2$ & 0.03955 & $-0.1787-0.2541$ & 0.7161 \\
\hline
\end{tabular}



ER $\beta$ mRNA levels cells by about 50\% (Fig. 6B). A similar effect of $i c b-1$ shRNA was observed after treatment of MCF-7 cells with vitamin $D_{3}$. Whereas this drug increased the expression of ER $\beta 1$ by about $60 \%$ in cells exhibiting normal $i c b$ - 1 levels, treatment with vitamin $\mathrm{D}_{3}$ resulted in significant down-regulation of both ER $\beta$ isoforms in MCF-7 icbKD cells by $>50 \%$.

Co-expression of icb-1 and E-cadherin in human breast cancer tissue. To test the results of our in vitro knockdownstudy in human tissue, we examined the expression of $i c b-1$, E-cadherin, ER $\alpha, E R \beta 1$ and ER $\beta 2$ in 66 breast cancer tissue samples by means of real-time PCR. From these breast cancer samples, 22 were graded G1 and were ER $\alpha$-positive, 22 were $\mathrm{G} 3$ and $\mathrm{ER} \alpha$-positive and 22 were G3 and ER $\alpha$-negative. When we compared the $i c b-1$ expression between the three subgroups, we did not observe significant differences (data not shown). To examine the correlation between the analyzed genes, we performed a non-parametric Spearman test. This test revealed a significant positive correlation of $i c b-1$ transcript levels with E-cadherin expression (Spearman's rho $0.2665, p=0.0126$ ) (Table II). We also observed a significant correlation with the $\mathrm{ER} \alpha$ transcript levels $(\mathrm{p}=0.0239)$, but not with the mRNA levels of the steroid hormone receptor variants ER $\beta 1$ or ER $\beta 2$.

\section{Discussion}

In the present study we have demonstrated the inhibition of vitamin $\mathrm{D}_{3}$ - and ATRA-induced differentiation in terms of regulation of the known differentiation-associated genes E-cadherin and lactoferrin and of the steroid hormone receptor ER $\beta$, as a result of $i c b-1$ knockdown. This observation and the shown co-expression between $i c b-1$ and E-cadherin in breast cancer tissue samples suggest the presence of an interplay between the two genes. Our in vitro data suggest that $i c b-1$ may play an important role on the signaling pathways, mediating differentiation signals like the retinoids or vitamin $\mathrm{D}_{3}$ and by stimulating the expression of differentiation-associated genes like the epithelial cell marker, E-cadherin. E-cadherin, the founding member of the cadherin superfamily of calciumdependent, transmembrane glycoproteins, is critical for the establishment of adherens-type junctions. E-cadherin plays an essential role in normal physiological processes, such as development, cell polarity, and tissue morphology, and in pathological states, such as the epithelial-mesenchymal transition (EMT), a process usually accompanied by tumor de-differentiation, infiltration, and metastasis. Inhibition of E-cadherin expression or function is common during EMT, an essential component of cancer progression to more aggressive phenotypes. In contrast, restoration of E-cadherin expression enhances intercellular adhesion, inhibits tumorigenicity, and suppresses the invasiveness of epithelial tumor cells. Both in breast and endometrial cancer, cellular differentiation has been associated with E-cadherin expression, and partial or complete loss of E-cadherin expression has been correlated with malignancy $(15,17-21)$. Considering these functions of E-cadherin, the observed inhibitory effect of $i c b-1$ knockdown on ATRA- and vitamin $\mathrm{D}_{3}$-induced $\mathrm{E}$-cadherin up-regulation suggests that loss of $i c b-1$ may block the differentiating, antiEMT effect of these drugs.

Derivates of vitamin $\mathrm{D}_{3}$ and retinoids are known to exert differentiating and anti-proliferative effects in multiple tissues $(14,22-24)$. Both agents act through a family of related nuclear receptors, the vitamin $\mathrm{D}_{3}$ receptor (VDR), the retinoid $\mathrm{X}$ receptor (RXR) and the retinoic acid receptor (RAR). After ligand binding, these receptors homo- or heterodimerize, bind to specific response elements in the promoter of target genes and serve as transcription factors $(10,25)$. With regard to the genes analyzed in this study, both the E-cadherin and lactoferrin genes have been previously reported to be responsive to vitamin $\mathrm{D}_{3}$ and ATRA $(9,10,13,14)$. However, only the lactoferrin gene was reported to contain a retinoic acid response element in its promoter, suggesting that regulation of E-cadherin expression by these substances is a more complex process $(11,12)$. Our data support the responsiveness of both genes to vitamin $\mathrm{D}_{3}$ and ATRA in MCF-7 breast cancer and HEC-1B endometrial adenocarcinoma cells. Regulation of $i c b-1$ gene expression itself by vitamin $\mathrm{D}_{3}$ further corroborates the involvement of this gene in cellular differentiation. However, the fact that ATRA did not have the same effect is in contrast to the results of our previous study in which this drug activated $i c b-1$ expression in HL-60 human promyelocytic leukemia cells, a difference which may be explained by tissue specificity (4).

Knockdown of the $i c b-1$ gene alone did not significantly affect E-cadherin expression, but unexpectedly strongly increased lactoferrin mRNA levels. The lactoferrin gene codes for a multifunctional iron-binding protein (26), which is found in numerous tissues and secretions, and especially in breast milk $(27,28)$. Lactoferrin expression is enhanced during processes such as pregnancy, involution or infections, and is a marker for differentiated mammary epithelial cells (26). Due to our previous data suggesting that the $i c b-1$ expression is associated with a differentiated phenotype, we did not expect the up-regulation of a differentiation-associated gene after $i c b-1$ knockdown. Our data suggest that the simple presence or absence of $i c b-1$ expression is not sufficient to induce or maintain a differentiated phenotype, but that extracellular signals such as ATRA and vitamin $\mathrm{D}_{3}$ are necessary as well. Consequently $i c b-1$ is suggested to exert its differentiation inducing capacities only in the presence of defined stimuli, as this gene might be a mediator of such differentiation signals. 
Our data suggest that the presence of $i c b-1$ may be necessary for maintenance of the high levels of E-cadherin, a gene which has been described to be a caretaker of the epithelial state (29). The fact that we demonstrated a positive correlation between $i c b-1$ and E-cadherin expression in human breast cancer tissue samples underlines the hypothesis and provides evidence for a role of the $i c b-1$ gene during differentiation processes.

Steroid hormone receptor expression is another marker for a differentiated phenotype of the breast and endometrial tumor cells. Particularly expression of ER $\beta$ has been reported to decline during carcinogenesis and to promote anti-tumoral effects (30). Thus, the decreased ER $\beta$ transcript levels observed both in MCF-7 and HEC-1B cells expressing $i c b-1$ shRNA may offer further support for the involvement of $i c b-1$ in cellular differentiation. The observed conversion of an ATRAand vitamin $\mathrm{D}_{3}$-induced up-regulation of $\mathrm{ER} \beta$ expression into a down-regulation of this steroid hormone receptor after $i c b-1$ gene silencing again supports the hypothesis that $i c b-1$ acts as an important mediator of such differentiation signals.

In conclusion, our data support a role of the $i c b-1$ gene in differentiation processes of cancer cells induced by ATRA or vitamin $\mathrm{D}_{3}$. Further studies elucidating the underlying molecular mechanisms will provide new insights into the $i c b-1$ gene function.

\section{Acknowledgements}

We thank Helena Houlihan for expert technical assistance.

\section{References}

1. Johnson AL, Aravind L, Shulzhenko N, Morgun A, Choi SY, Crockford TL, Lambe T, Domaschenz H, Kucharska EM, Zheng L, Vinuesa CG, Lenardo MJ, Goodnow CC, Cornall RJ and Schwartz RH: Themis is a member of a new metazoan gene family and is required for the completion of thymocyte positive selection. Nat Immunol 10: 831-839, 2009.

2. Patrick MS, Oda H, Hayakawa K, Sato Y, Eshima K, Kirikae T, Iemura S, Shirai M, Abe T, Natsume T, Sasazuki T and Suzuki H: Gasp, a Grb2-associating protein, is critical for positive selection of thymocytes. Proc Natl Acad Sci USA 106: 16345-16350, 2009.

3. Treeck O, Strunck E and Vollmer G: A novel basement membrane-induced gene identified in the human endometrial adenocarcinoma cell line HEC1B. FEBS Lett 425: 426-430, 1998.

4. Treeck O, Odani T, Itoh N, Imai H, Fujita S, Kohroki J, Nakanishi T, Diedrich K, Ortmann O, Tanaka K and Vollmer G: Detection of increased icb-1 transcript levels in maturing HL-60 cells: a novel marker for granulocytic and monocytic in vitro differentiation. Leuk Res 26: 765-769, 2002.

5. Treeck O, Kindzorra I, Pauser K, Treeck L and Ortmann O: Expression of icb-1 gene is interferon-gamma inducible in breast and ovarian cancer cell lines and affects the IFN gammaresponse of SK-OV-3 ovarian cancer cells. Cytokine 32: 137-142, 2005.

6. Bollmann J, Ortmann O and Treeck O: Expression of differentiation-associated gene icb-1 is estrogen-responsive in ovarian and breast cancer cell lines. J Steroid Biochem Mol Biol 109: 16-21, 2008.

7. Konwisorz A, Springwald A, Haselberger M, Goerse R Ortmann $\mathrm{O}$ and Treeck O: Knockdown of icb-1 gene enhanced estrogen responsiveness of ovarian and breast cancer cells. Endocr Relat Cancer 17: 147-157, 2010.

8. Springwald A, Lattrich C, Seitz S, Ortmann O and Treeck O: Single nucleotide polymorphisms in human gene icb-1 and breast cancer susceptibility. Cancer Invest 27: 669-672, 2009.
9. Dutta A, Sen T, Banerji A, Das S and Chatterjee A: Studies on multifunctional effect of all-trans retinoic acid (ATRA) on matrix metalloproteinase-2 (MMP-2) and its regulatory molecules in human breast cancer cells (MCF-7). J Oncol 2009: 627840, 2009.

10. Wang Q, Lee D, Sysounthone V, Chandraratna RAS, Christakos S, Korah R and Wieder R: 1,25-dihydroxyvitamin D3 and retonic acid analogues induce differentiation in breast cancer cells with function- and cell-specific additive effects. Breast Cancer Res Treat 67: 157-168, 2001.

11. Giancotti V: Breast cancer markers. Cancer Lett 243: 145-159, 2006.

12. Lee MO, Liu Y and Zhang XK: A retinoic acid response element that overlaps an estrogen response element mediates multihormonal sensitivity in transcriptional activation of the lactoferrin gene. Mol Cell Biol 15: 4194-4207, 1995.

13. Carter CA: Retinoic acid signaling through PI 3-kinase induces differentiation of human endometrial adenocarcinoma cells. Exp Mol Pathol 75: 34-44, 2003.

14. Yabushita H, Hirata M, Noguchi M and Nakanishi M: Vitamin D receptor in endometrial carcinoma and the differentiationinducing effect of 1,25-dihydroxyvitamin D3 on endometrial carcinoma cell lines. J Obstet Gynaecol Res 22: 529-539, 1996.

15. Bansal N, Yendluri V and Wenham RM: The molecular biology of endometrial cancers and the implications for pathogenesis, classification, and targeted therapies. Cancer Control 16: 8-13, 2009.

16. Livak KJ and Schmittgen TD: Analysis of relative gene expression data using real-time quantitative PCR and the 2(-Delta Delta C(T)) method. Methods 25: 402-408, 2001.

17. Cano A, Pérez-Moreno MA, Rodrigo I, Locascio A, Blanco MJ, del Barrio MG, Portillo F and Nieto MA: The transcription factor snail controls epithelial-mesenchymal transitions by repressing E-cadherin expression. Nat Cell Biol 2: 76-83, 2000.

18. Damsky CH, Richa J, Solter D, Knudsen K and Buck CA: Identification and purification of a cell surface glycoprotein mediating intercellular adhesion in embryonic and adult tissue. Cell 34: 455-466, 1983.

19. Halbleib JM and Nelson WJ: Cadherins in development: Cell adhesion, sorting, and tissue morphogenesis. Genes Dev 20: 3199-3214, 2006.

20. Perl AK, Wilgenbus P, Dahl U, Semb H and Christofori G: A causal role for E-cadherin in the transition from adenoma to carcinoma. Nature 392: 190-193, 1998.

21. Wijnhoven BP, Dinjens WN and Pignatelli M: E-cadherincatenin cell-cell adhesion complex and human cancer. Br J Surg 87: 992-1005, 2000.

22. Elstner E, Linker-Israeli M, Said J, Umiel T, de Vos S, Shintaku IP, Heber D, Binderup L, Uskokovic M and Koeffler HP: 20-epivitamin D3 analogues: a novel class of potent inhibitors of proliferation and inducers of differentiation of human breast cancer cell lines. Cancer Res 55: 2822-2830, 1995.

23. Mathiasen IS, Hansen CM, Foghsgaard L and Jäättelä M: Sensitization to TNF-induced apoptosis by 1,25-dihydroxy vitamin $\mathrm{D}(3)$ involves up-regulation of the TNF receptor 1 and cathepsin B. Int J Cancer 93: 224-231, 2001.

24. Wu G, Fan RS, Li W, Ko TC and Brattain MG: Modulation of cell cycle control by vitamin D3 and its analogue, EB1089, in human breast cancer cells. Oncogene 15: 1555-1563, 1997.

25. Green S and Chambon P: Nuclear receptors enhance our understanding of transcription regulation. Trends Genet 4: 309-314, 1988.

26. Baumrucker CR, Schanbacher F, Shang Y and Green MH: Lactoferrin interaction with retinoid signaling: cell growth and apoptosis in mammary cells. Domest Anim Endocrinol 30: 289-303, 2006

27. Anderson BF, Baker HM, Dodson EJ, Norris GE, Rumball SV, Waters JM and Baker EN: Structure of human lactoferrin at 3.2-A resolution. Proc Natl Acad Sci USA 84: 1769-1773, 1987.

28. Legrand D, Pierce A, Elass E, Carpentier M, Mariller C and Mazurier J: Lactoferrin structure and functions. Adv Exp Med Biol 606: 163-194, 2008.

29. Prasad CP, Rath G, Mathur S, Bhatnagar D, Parshad R and Ralhan R: Expression analysis of E-cadherin, Slug and GSK3 $\beta$ in invasive ductal carcinoma of breast. BMC Cancer 9: 325, 2009.

30. Lindberg K, Ström A, Lock JG, Gustafsson JA, Haldosén LA and Helguero LA: Expression of estrogen receptor beta increases integrin alpha1 and integrin beta1 levels and enhances adhesion of breast cancer cells. J Cell Physiol 222: 156-167, 2010. 